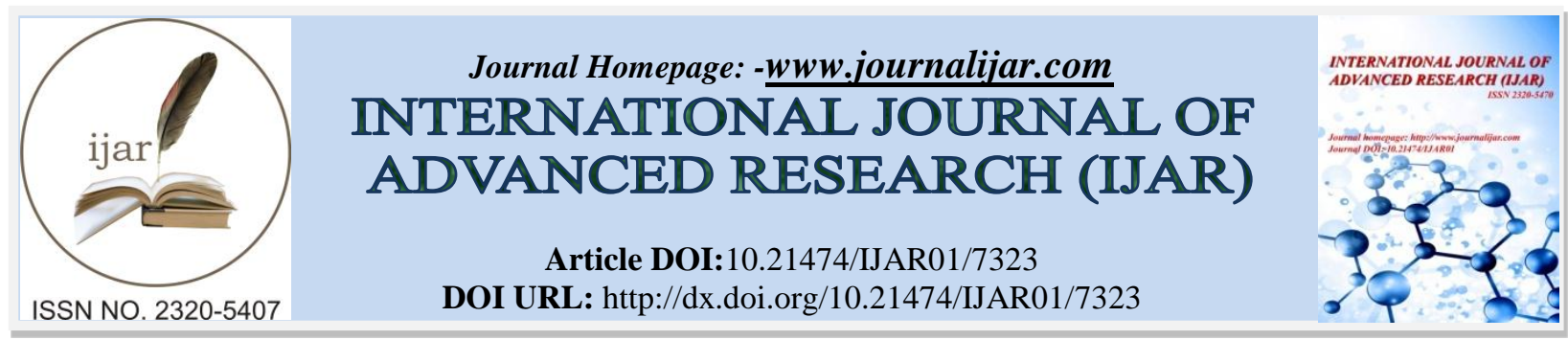

RESEARCH ARTICLE

\title{
THE POLITICAL PARTIES SIMPLIFICATION TO STABILIZING THE PRESIDENTIAL GOVERNMENT IN INDONESIA.
}

\author{
Risbar Berlian Bachri ${ }^{1}$, Achmad Ruslan ${ }^{2}$ and Marwati Riza ${ }^{2}$. \\ 1. Graduate School, Faculty of Law, Hasanuddin University. \\ 2. Faculty of Law, Hasanuddin University.
}

\section{Manuscript Info}

Manuscript History

Received: 19 April 2018

Final Accepted: 21 May 2018

Published: June 2018

Keywords:-

Political Parties, Presidential

Government, Simplification, Stability.

\begin{abstract}
Structuring of a political party is a constitutional national law politics insofar as it is consistent with the principle of protection of Human Rights and the principle of democracy. The legitimate principles of restriction of human rights consist of the principle of legality and the principle of interest to exercise restriction. The application of the two principles within the framework of restrictions on Human Rights is also overseen and offset by the principle of proportionality. Political law in the framework of structuring political parties is aimed at two targets, that is: (1) the regulation on the establishment of political parties and (2) the regulation of the holding of elections. The regulatory orientation of the establishment of political parties is intended to be an impediment to the will of a person to form a random political party. While the regulatory orientation on the holding of elections is to limit or reduce the number of political party presence in parliament. The factors influencing the structuring of political parties in Indonesia are sociopolitical factors, the ineffectiveness of party system adopted by the State of Indonesia, the juridical factor by tightening the terms of the establishment of political parties in the Election Law and the Political Party Law, the condition of pluralism a nation intended to minimize the flow politics, as well as historical conditions that show the historical facts of political parties in Indonesia are quite bleak.
\end{abstract}

Copy Right, IJAR, 2018,. All rights reserved.

\section{Introduction:-}

Times are changing, human ideas to answer the challenges of the times must also change. The constantly changing political, economic, social and other conditions required to adapt the applicable legal provisions, so that they continue to function fairly both by means of order keepers and as drivers of change to bring about prosperity and social justice for all the people.

Criticisms of inconsistency and incoherence between the preamble of the 1945 Constitution of the State of the Republic of Indonesia and amendments also arise because of the tendency of liberalism in amendments that are seen to be contrary to the basic philosophy and normative basis in the Preamble of the 1945 Constitution of the State of 
the Republic of Indonesia. ${ }^{1}$ A similar situation is embedded in the agreement on the Unitary State of the Republic of Indonesia which turns out in its implementation on the body just opposite to the basic agreement. Amendment provisions on the system of regional government in Article 18 paragraph (5) of the 1945 Constitution of the State of the Republic of Indonesia precisely tends toward federalism, ${ }^{2}$ thus contrary to Article 1 paragraph (1) which determines the form of a unitary state. ${ }^{3}$ a presidential government system that is less common or less than perfect. ${ }^{4}$

The researcher sees the impractical implementation of the constitutional design of presidential government system with party system developed through political practice, multiparty system in Indonesia. This is reflected in the practice of relations between the presidential institution and the legislature that goes beyond the spirit of the postamendment of the 1945 Constitution of the State of the Republic of Indonesia which seeks to impose a presidential system of government more purely than before. One source of the problem lies in a multiparty system that proves unable to produce a solid legislative body because the seats in the House of Representatives are distributed by many political parties with different political and ideological interests.

Consequently, as the president and his supporting political party are unable to secure a majority seat in the House of Representatives so that the president who receives a direct mandate from the people beyond the vote of the political party is forced to take a large coalition of political parties in parliament to secure his policies. Therefore a minor assessment of this practice by saying that the current political "cow trade policy" between the House of Representatives and the president is very precise.

Therefore, whoever becomes president doesn't need to be half-hearted in carrying out the trust or mandate of the people. ${ }^{5}$ The authors argue that the proliferation of political parties and the number of political parties that compete for the seat of the House of Representatives in legislative elections is a problem that should be given a solution for presidential government system is truly operational.

The number of political parties that compete in elections will not be able to produce a winner with a majority of seats in the House of Representatives so that the implication of a coalition that is nothing but the model of "forced marriage" is bound by short-term political interests: securing the president's policy agenda and for cabinet seats. Such practices essentially undermine the presidential authority directly elected by the people and have specific and independent constitutional authority in the 1945 Constitution of the State of the Republic of Indonesia as the embodiment of the presidential government system. Political participation of citizens through political parties is the embodiment of Human Rights, Article 28E Paragraph (3) of the 1945 Constitution of the Republic of Indonesia: "Everyone has the right to freedom of association, assembly and dispute opinion." As part of Human Rights, the political expression conveyed through the organization of this political party doesn't belong to the category of absolute rights.

The main idea to be developed by writing was the legal principles for forming political parties Indonesia in 1945, because the current political practice is an anomalous form that must be immediately normalized. At the next level, the principles are then elaborated into the rules to be considered in administering the ideal law, that is the law, which will include two dimensions: party political participation in appropriate electoral contestation and supporting the presidential government system of the 1945 Constitution of the State of the Republic of Indonesia.

Based on these legal principles, justification reasons for limiting political parties in Indonesia should be justifiable and non-arbitrary arguments. The legitimate constitutional basis for restricting human rights in general and restrictions on political parties in particular, Article 28i Paragraph (2) of the 1945 Constitution of the State of the Republic of Indonesia: "In exercising their rights and freedoms, everyone is subject to restrictions which is

\footnotetext{
${ }^{1}$ Aidul Fitriciada Azhari, 2006,Evaluasi Proses Amandemen UUD 1945: Dari Demokratisasike Perubahan Sistem, Jurnal Ilmu Hukum, Vol. 9, September 2006, p. 164.

2 Jimly Asshiddiqie, Pengantar Pemikiran tentang Rancangan Perubahan UUD Negara Kesatuan Republik Indonesia, Jakarta : The Habibie Center, 2001, p.28-29

${ }^{3}$ Aidul Fitriciada Azhari, 2006,Evaluasi Proses Amandemen UUD 1945: Dari Demokratisasike Perubahan Sistem, Jurnal Ilmu Hukum, Vol. 9, September 2006, p. 164

${ }^{4}$ T.A. Legowo, Artikel Menyempurnakan Sistem Presidensial, p. 1-2

${ }^{5}$ Amien Rais, "Kata Pengantar," dalam Hanta Yuda AR, Op.cit., p. xxii.
} 
established by law with the sole intent of ensuring the recognition and respect for the rights of freedom of another person.

The author wishes to develop a comprehensive legal argument on legal principles to limit political parties in Indonesia within the framework of the presidential government system of the 1945 Constitution of the State of the Republic of Indonesia. Arrangements on the establishment of political parties and arrangements concerning the participation of political parties in election contestations are appropriate and supporting the presidential government system of the 1945 Constitution of the State of the Republic of Indonesia and maintaining its conformity with the substantive conditions contained in Article 28J Paragraph (2) of the 1945 Constitution of the State of the Republic of Indonesia: "recognition and respect for the rights of freedom of others fair demands in accordance with moral considerations, religious values, security, and public order in a democratic society."

The reinforcing argument that will also be studied further is that the multiparty system is not always identical with the attributes of a democratic system of government (as opposed to an authoritarian system of government). The author doesn't agree with the thesis that it is believed that the multiparty system is the most appropriate to democracy because it gives the widest possible freedom for everyone to associate in order to convey his political aspirations and participate in government."

\section{Method of the Research:-}

The selected research location is in the city of Jakarta namely the General Election Commission and the House of Representatives of the Republic of Indonesia, the main reason the authors chose the location in Jakarta because the city of Jakarta is the capital of the state or central government that in fact has a heterogeneous society and full of complex problems, specific to the General Election Commission and the House of Representatives of the Republic of Indonesia, both of which are centers of political institutions in Indonesia. This research is normative legal research or literature research method, where the method used in this research by examining the existing legal material.

\section{Results and Discussion:-}

\section{Arrangement of Political Party in Indonesia:-}

Arrangements on the Establishment of Political Parties in the Framework of the Simplification of Political Parties The arrangement of the establishment of political parties in the context of simplification of political parties is based on the following arguments. First, the use of the right and freedom of association as a basis for legitimacy in the act of establishing political parties by citizens should be done fairly.

Substantive Requirements of Establishment of Political Parties The main basis of the arrangement of the establishment of a political party is the right to freedom of association or assembly. Hence the substantive requirement of the establishment of a political party is within the framework to accommodate that right, the right to freedom of association or assembly, as a top priority on the one hand, and the ultimate purpose of that right on the other side.

Every citizen is in principle recognized and guaranteed to have the right to freedom of association/assembly. However, on the other hand, any person who wishes to express that right by establishing a political party shall be subject to and comply with applicable legal provisions which have been incorporated into law. The legislator has a policy in determining such arrangements. As long as there is no cancellation by the competent body, the Constitutional Court, the law is in force and must be obeyed by anyone when it wants to establish a political party.

Jimly Asshidiqie outlines that based on the practice of states, the regulatory model of political parties is twofold. First, countries that don't recognize any arrangements that lead to the prohibition and dissolution of political parties. These countries for example are Belgium, Greece, and Austria. Secondly, are the countries that set the objectives and activities of political parties and certain sanctions of violations.

The substance of the regulation can be classified into 12 variations, namely: (1) the party must actively have activities as a registration requirement; (2) the party has the purpose of being "unlawful or immoral aims", not listed or dissolved; (3) the prohibition of party activities that endanger human rights, is totalitarian, contrary to the principle of "rule of law and democracy", popular sovereignty, pluralism, partial equality, separation of powers, and judicial independence; (4) prohibition of extremist parties; (5) parties that disseminate, teach, or fight for hatred, 
violence, or discrimination are also prohibited and threatened with dissolution; (6) a prohibition on parties that engage in activities of anti-democratic violence; (7) the prohibition of parties that threaten the existence and independence of the state; (8) party bans threatening the territorial integrity of the country; (9) the prohibition of parties advocating crime; (10) the party shall not take over the activities which are the duty of the state; (11) prohibition of activities in certain neighborhoods; and (12) prohibition of "para-military" activity. ${ }^{6}$

\section{Factors Affecting the Structuring of Political Parties in Indonesia:-}

The perfection of the political system in general and the system of government in particular is the collective agenda of our nation, then there are two strategies of improvement that can be done, (1) a fundamental refinement that requires a change or re-amendment of the 1945 Constitution of the State of the Republic of Indonesia; and (2) a gradual improvement through improvement and revision of all political legislation.

Ideally these improvements should be done basically at once. However, due to various objective considerations such as its feasibility, and the risks and political costs that may result, gradual improvement through the revision of the Political Law is the most realistic option.

In the framework of gradual improvements that are short-term, at least done the arrangement and refinement to realize a democratic political system in order to support an effective presidential system, namely the improvement of party system. Researchers try to discuss the factors that influence the structuring of Political Parties in Indonesia;

\section{Sociological Factors}

The history of partying experience in Indonesia since the reformation era indicates that it is problematic that the applicable electoral threshold provisions produce political processes that are viewed and impacted in parliament on low legislation products, weak supervisory functions, and ineffectiveness of parliamentary work in general. Theoretically, the degree of party fragmentation - in this case the number of parties is a factor determining the structure of competition between parties, the interaction and stability of government.

Meanwhile, the party polarization level, the ideological distance between parties, determines the quality of political stability, conflict, and voter loyalty to the party. Thus low levels of fragmentation and party polarization tend to make governance easier and more effective for the executive, and conversely, high levels of party fragmentation and polarization tend to weaken governance, and make it difficult to achieve consensus between parties, as well as between parliament and government.

In order to realize a presidential system of government and a strong representation system, and electoral systems encourage the establishment of multiparty systems with low levels of party fragmentation and polarization, or at least moderate party fragmentation and polarization. In addition to party system factors, the quality of the institutionalization of parties internally and the quality of party leadership also greatly determines the effectiveness of party work and party system in the democratic system. Therefore, the improvement of the party system should be seen as an inseparable agenda of strengthening the presidential government system on the one hand and strengthening the representative system on the other.

In addition to supporting a strong and effective presidential system, the election-based party system should condition a coalition between parties on the same ideological basis and or political platform.

In relation to the desire to create a party system to strengthen and streamline the presidential system, there are at least four objectives that are the goal of improving the party system through the Political Party Act. The four targets are (1) to establish a simple multiparty system; (2) encouraging the creation of effective and credible party institutionalization; (3) conditioned the formation of a democratic and accountable party leadership; and (4) encouraging the strengthening of base and party structure at the grassroots level.

Experience in the 2004 legislative elections implements a proportional representation system, which in its implementation shows the role of political parties is very dominant compared with the role of constituents in the acquisition of seats in the representative institutions of the people. The values of democracy basically provide a direction for the balance of the proportional role of political parties with constituent votes. Such democratic

\footnotetext{
${ }^{6}$ M. Ali Safa'at, Teori Hans-Kelsen Tentang Hukum, Konstitusi Pres, Jakarta, 2007, p. 27
} 
directives will be able to absorb the political aspirations of the people, especially their constituents in providing a quality and significant contribution to the welfare of the people.

In the context of the presidential and vice presidential elections, the election of regional heads and deputy regional heads of the past is given the opportunity to political parties that don't comply with the requirement to join in the promotion of presidential candidates and vice-presidents or prospective heads of regions and deputy regional heads.

In its implementation, sometimes there is a joint political behavior of the party which will be the president and vice president candidate or the candidate of the regional head and the deputy head of the region who should be consistent in executing the agreement by supporting the performance of the elected candidate until his/her term of office, because his support contains the meaning of ethical politics and democratic ethics. In reality it doesn't happen as described above. The meaning of political ethics and democratic ethics is expected to give encouragement to political parties to strengthen the performance of elected candidates in carrying out their positions.

\section{Juridical Factors:-}

The presidential government system based on the Unitary State of the Republic of Indonesia Act of 1945 constitutes an appropriate political choice if it is linked to Indonesian vast geographical range, highly heterogeneous in politics and culture, as well as the obsession with decentralization of governance and regional autonomy. Especially when it is related to the history of the nation that is almost always colored by political instability, and the nation's need for more definite and measurable mechanisms and circulation of leadership.

The development of political life based on the 1945 Constitution has spawned Law Number 31 Year 2002 regarding Political Party which puts political party as one of the important form of community participation in developing democratic life that uphold freedom, equality, togetherness and honesty. Whereas Law Number 31 Year 2002 regarding Political Parties in the implementation of experience has so far led to the desire to change because it is not in accordance with the development of society and changes in state administration.

Similarly, the implementation of the General Elections based on Law Number 12 Year 2003 regarding General Election of Members of the People's Legislative Assembly, Regional Representatives Council and Regional House of Representatives. In the implementation of the election shows the role and dynamics of political parties that ultimately lead to juridical problems, when in turn will provide political roles in the 2009 elections.

The linkage is that Law Number 31 Year 2002 on Political Parties should be made perfecting. In relation to the implementation of Law Number 23 Year 2003 regarding the General Election of President and Vice President, the role of political parties that carries the President and Vice Presidential candidate hasn't seen any support for the strengthening of presidential performance during his term on one side, Of the 1945 Constitution of the State of the Republic of Indonesia Article 6A paragraph (2) has provided a solid basis for the existence of a coalition of political parties.

In Law Number 31 Year 2002 on Political Parties there is no regulation on this matter. To implement the constitutional basis, it is necessary to improve the Law on political parties. Based on the above considerations, the revision of Law Number 31 Year 2002 regarding Political Parties in principle has a juridical basis relevant to the implementation of Law Number 12 Year 2003 regarding General Election, Law Number 22 Year 2003 on the Composition and Status of the Consultative Assembly The People's Legislative Assembly, the Regional Representative Council and the Regional People's Legislative Assembly, Law Number 23 Year 2003 regarding the General Election of President and Vice President.

\section{Pluralistic Factors of the Nation:-}

Indonesia is a country that has a very high level of community plurality and also has a very complex social plurality. Indonesian society consists of various ethnic, religious, and regional identities. Social segregation of society almost has a direct relationship with the typology of political parties in Indonesia. One of them is evidenced by the formation of Indonesian political parties, which are mostly based on certain ideological and political factors. 
In the opinion of Hanta Yuda AR, the multiparty system is relatively more able to reflect the strength of power in society, therefore the complexity of the pluralism of Indonesian society is directly proportional to the typology of multi-party system. ${ }^{7}$

In this discussion, the authors agree with the opinion of Hanta Yuda AR, that Indonesia is implementing multiparty system more reflect the strength of power in society, with the pluralism in Indonesia is high enough to have various tribes, races, regions, and religions, so multiparty system is also very representative for the people of Indonesia, and the plurality of people is also a major factor or form factor. This pluralism should be a fundamental reason for organizing this diverse political party in Indonesia.

\section{Historical Factors:-}

The history and construction of political culture in a nation has an effect on the institutionalization of party system in a country. This historical factor indirectly affects the institutionalization of the party system. For example, in the history of the party trip of a country that has long institutionalized the multiparty system, its people have indirectly internalized with differences and heterogeneity, thus affecting the construction of political culture. The maturity of a nation's political culture can be observed from the harmony between the cultural aspects of the nation and its political structure. ${ }^{8}$

Historical and socio-cultural factors (culture) of this society is a factor pushing partying process in Indonesia. The building of a party system in Indonesia is influenced by a strong cultural background. The condition of Indonesian political culture also gives a picture that the reality of Indonesia is very diverse. Political parties that are formed also can't be separated from the politics of the flow.

Regarding the background of Indonesia embrace multiparty system based on history and political culture, I agree with Bambang Istianto. That the party of political parties formed in Indonesia can't be separated from the politics of the flow which shows the high plurality of the ideological spectrum and culture of Indonesian society, so that the long-standing political culture factor in Indonesian society tends to support the institutionalization process of multiparty system and in the Indonesian political context, multiparty system is a system that is difficult to avoid. ${ }^{9}$

The mechanism required to overcome the number of existing Political Parties to simplify the number of political parties, namely the agenda of designing of political institutions to be designed and reorganized, among others:

Simplification of Political Parties as Election Participants To simplify the number of political parties participating in the election can be done in several ways, namely:

Fulfilling the Eligibility Requirements of Election Contesting Political Parties in a consistent manner the General Elections Commission shall implement all provisions on the requirements of political parties to be Election Contestants consistently, and perform administrative and factual verification of all requirements. If a political party is approved as a legal entity of the Department of Law and Human Rights, then a political party shall meet a number of more competitive requirements to be eligible as Election Contestants as stipulated in the Electoral Law.

Implementing a Competition System of Election Contesting Political Parties that categorizes the Political Parties Participants in the General Election into three scopes: 1. Political Parties Participants in General Election Scope of City or City Can Only be a Member of the General Election of Members of the Regional House of Representatives only. 2. Political Parties Participants in the General Election The scope of the Province may only be a Member of the General Elections of the Members of the Regional House of Representatives of the Regency/City and General Election of the Provincial People's Legislative Assembly. 3. Political Parties Participating in the General Election Scope Becoming Election Contestants of Members of the Regional House of Representatives of the Regency/City, General Election of Members of the Provincial House of Representatives, and General Election of Members of the People's Legislative Assembly.

\footnotetext{
${ }^{7}$ Hanta Yuda AR, Presidensialisme Setengah Hati; Dari Dilema ke Kompromi, (Jakarta:PT Gramedia Pustaka Utama), 2010, p. 27

${ }^{8}$ Hanta Yuda AR, op.cit, hlm.28. DIPONEGORO LAW REVIEW Volume 5, Nomor 2, Tahun 2016

${ }^{9}$ Bambang Istanto, Potret Buram Politik Indonesia, (Jakarta:Mitra Wacana Media), 2014, p.88.
} 


\section{Simplification of Political Parties in Parliament:-}

a. Implementing a plurality/majority system or mixed member proportional system as one form of institutional engineering to a simple multi-party strategy, the strategy of shifting from a proportional system to a district system or at a minimum with a mixed system deserves to be one of the systems strengthening agenda more effective and stable presidency through the reorganization of electoral system design.

Minimizing the Electoral District The magnitude of the district shall be the number of parliamentary seats or members of the People's Legislative Assembly to be elected in an electoral district. There are two groups of district magnitudes (electoral districts), namely single-member (single-seat) electoral districts and multiple members (several seats).

Applying Parliamentary Thresholds in Parliament Consistently not exactly the number of electoral political parties that should be limited, but the ideal number of political parties that need to be empowered or streamlined in parliament. The application of parliamentary threshold is far more effective than ET in streamlining the number of political parties in the House of Representatives. the parliamentary threshold is more effective in reducing the number of political parties participating in the election because of its more obvious political consequences.

Combining Legislative Election and Presidential Election (Concurrent Elections). If the holding of legislative and presidential elections is held together, then an effective government will be created. The elected president will gain strong legitimacy from the people and gain strong support from parliament.

Fractional Threshold simplifies the number of fractions by tightening fractional threshold requirements. The government will run more effectively if there are 3 or 4 factions in parliament. One example of requirements for fraction formation is that it can only be done if a political party has at least 50 or even 100 seats in parliament.

Regulation of the Permanent Coalition for a strong and solid coalition to be created, the coalition needs to be built on the basis of ideality or platform. Political parties need to be encouraged to conduct a permanent coalition in order to form a majority power that will sustain a strong government.

Political Parties in Indonesia Since the enactment of the Constitution of the State of the Republic of Indonesia Year 1945 Simplification of the number of political parties in addition to saving costs, also provides more conducive and qualified political lessons. Qiblah political party is not only to power, but rather focus on the quality of political parties by looking at policies that increase people's trust. That the parties are not too much can be more focused to build people's welfare, political mechanisms in the representatives of the people can be more efficient and effective. The position of the President as head of government and head of state can be more focused overseen by the legislature. We no longer see the power of political parties from money politics, but we can live in a systematic, effective and efficient and transparent political atmosphere. Because indirectly, political parties who lose as opposition will control the government strictly and qualified.

\section{Conclusions:-}

Political law in the framework of structuring political parties is aimed at two targets, that is: (1) the regulation on the establishment of political parties and (2) the regulation of the holding of elections. The regulatory orientation of the establishment of political parties is intended to be an impediment to the will of a person to form a random political party. While the regulatory orientation on the holding of elections is to limit or reduce the number of political party presence in parliament.

The factors influencing the structuring of political parties in Indonesia are socio-political factors, namely the ineffectiveness of party system adopted by the State of Indonesia, the juridical factor by tightening the terms of the establishment of political parties in the Election Law and the Political Party Law, the condition of pluralism the nation meant to minimize the flow politics, as well as the historical requirements that show the historical facts of political parties in Indonesia are quite bleak. 


\section{References:-}

1. Aidul Fitriciada Azhari, 2006,Evaluasi Proses Amandemen UUD 1945: Dari Demokratisasike Perubahan Sistem, Jurnal Ilmu Hukum, Vol. 9, September 2006.

2. Amien Rais, "Kata Pengantar," dalam Hanta Yuda AR, Op.cit., p. xxii.

3. Bambang Istanto, Potret Buram Politik Indonesia, (Jakarta:Mitra Wacana Media), 2014.

4. Catur Wido Haruni, Urgensi dan Implikasinya Pemilihan Presiden secara Langsung terhadapPenyelenggaraan Pemerintahan di Indonesia, Legality Jurnal Ilmiah Hukum, Vol.13, Nomor.2, Malang September 2005-Februari 2006, UMM Press.

5. Hanta Yuda AR, Presidensialisme Setengah Hati; Dari Dilema ke Kompromi, (Jakarta:PT Gramedia Pustaka Utama), 2010.

6. Jimly Asshiddiqie, Pengantar Pemikiran tentang Rancangan Perubahan UUD Negara Kesatuan Republik Indonesia, Jakarta : The Habibie Center, 2001.

7. M. Ali Safa'at, Teori Hans-Kelsen Tentang Hukum, Konstitusi Pres, Jakarta, 2007.

8. Misranto, Amandemen Undang-undang 1945 dalam Perspektif Perkembangan, diterbitkan pada Legality, Jurnal Ilmiah Hukum, Vol. 14

9. Sri Budi Eko Wardarni, 2007, "Koalisi Partai Politik dalam Pemilihan KepalaDaerah Secara Langsung : Kasus Pilkada Profinsi Banten Tahun 2006," Tesis,Program Pasca Sarjana Ilmu Politik FISIP UI, Jakarta."

10. T.A. Legowo, Artikel Menyempurnakan Sistem Presidensial. 